\title{
Efektivitas outdoor study untuk meningkatkan hasil belajar Geografi berdasarkan locus of control di sekolah menengah atas Kota Palembang
}

\author{
Cintami $^{\text {a, }}{ }^{*}$, Mukminan ${ }^{\text {b, } 2}$ \\ ${ }^{a, b}$ Program Studi Pendidikan Geografi Program Pascasarjana Universitas Negeri Yogyakarta, Yogyakarta, \\ Indonesia \\ ${ }_{1}^{1}$ chintami91@gmail.com*; mukminan@yahoo.co.id
}

*korespondensi penulis

\begin{tabular}{ll}
\hline Informasi artikel & ABSTRAK \\
\hline Kata kunci: & Penelitian ini bertujuan untuk mengetahui efektivitas outdoor study untuk meningkatkan \\
Hasil belajar & hasil belajar geografi berdasarkan locus of control di SMA Kota Palembang. Penelitian ini \\
Geografi, & merupakan penelitian kuantitatif dengan pendekatan Quasi Experiment. Teknik analisis \\
Locus of control & data menggunakan analisis two way anova. Hasil penelitian ini menunjukkan: 1) terdapat \\
& interaksi antara metode pembelajaran dan locus of control terhadap hasil belajar kognitif \\
& sehingga outdoor study lebih efektif untuk peserta didik bertipe extrovert dan outdoor \\
& study tidak efektif untuk peserta didik bertipe introvert, dan 2) terdapat interaksi antara \\
& metode pembelajaran dan locus of control terhadap sikap peduli lingkungan sehingga \\
& outdoor study lebih efektif untuk peserta didik bertipe extrovert dan outdoor study tidak \\
& efektif untuk peserta didik bertipe introvert.
\end{tabular}

\section{Keywords:}

Outdoor study, Geography

learning

outcomes,

Locus of control

\section{ABSTRACT}

This research aims to reveal: The effectiveness of outdoor study to improve the geography learning outcomes based on the locus of control in Senior High School (SMA) in the City of Palembang. Rol toward the geography learning outcomes and environmental awareness in SMA Palembang City. This research was a quantitative research with the quasi experiment approach. The data analysis techniques used two way anova analysis. The results of this research are as follows: 1) there is interaction between learning method and locus of control on the cognitive learning so that more effect outdoor study for learners of type extrovert and outdoor study is not effect for learners of type introvert, and 2) there is interaction between learning method and locus of control on a caring attitude to the outdoor study more effect study for learners of type extrovert and outdoor study is not effect for learners of type introvert.

Copyright (C) 2018 Cintami dan Mukminan. All Right Reserved

\section{PENDAHULUAN}

Instruksional atau pengajaran adalah proses interaksi yang secara langsung antara guru dan siswa, yang bertujuan untuk memperoleh pengetahuan, keterampilan, dan sikap. Pengajaran yang efektif merupakan proses sirkuler, yaitu berupa lingkaran yang terdiri atas empat komponen, yakni: mengadakan asesmen, mendiagnosis, merencanakan, mengajar dan membimbing latihan/reinforcement (Nasution, 2006, hal. 102-103).
Prinsip keefektifan dapat ditinjau dari dua dimensi, yaitu proses dan produk. Dimensi proses mengacu pada keefektifan proses pembelajaran sebagai real curriculum (keefektifan guru mengajar dan keefektifan peserta didik belajar). Adapun dimensi produk mengacu pada hasil yang ingin dicapai peserta didik (Arifin, 2011, hal. 33).

Hasil belajar mencangkup kemampuan kognitif, efektif dan psikomotorik. Hasil belajar adalah pola-pola perbuatan, nilai-nilai, 
pengertian-pengertian, sikap-sikap, apresiasi dan keterampilan (Suprijono, 2009, hal. 6-7).

Ilmu geografi mempelajari permukaan bumi dan bagaimana manusia mempengaruhi dan dipengaruhi oleh lingkungan alam sekitar, merupakan ilmu pengetahuan yang paling banyak berkaitan dalam interaksi kehidupan manusia sehari-hari yang berinteraksi dengan alam sekitar yaitu lingkungan hidup kita baik dengan alam, hewan maupun tumbuhtumbuhan.

Banyak guru beranggapan, mengajar itu di dalam ruang kelas. Belajar itu sambil duduk manis, guru menerangkan, dan anak didik mendengarkan dengan saksama. Belajar itu guru memberikan tugas dan anak didik mengerjakannya. Guru mempunyai metode sendiri dalam pembelajaran. Anak-anak di dalam kelas, jelas terkadang jenuh, mereka merasa bosan dengan lingkungan yang itu-itu saja. Coba ajak mereka ke luar kelas, bermain di taman atau kebun binatang, misalnya: Bermain di sekitar pantai atau pegunungan (Assa, 2015, hal. 97).

Pembelajaran di luar kelas (outdoor study) merupakan upaya untuk mengarahkan siswa untuk melakukan aktivitas yang dapat membawa mereka mengamati lingkungan sekitar, sesuai dengan materi yang diajarkan. Sehingga, pendidikan di luar kelas lebih mengacu pada pengalaman dan pendidikan lingkungan yang sangat berpengaruh pada kecerdasan siswa. Sejalan dengan pemikiran Smith dalam Sumarmi yang menyata-kan bahwa "studi lapangan mempunyai kekuatan untuk mengaplikasikan ide secara umum yang ada di kelas ke dalam dunia nyata” (Danarti, 2014, hal. 103).

Outdoor study adalah metode di mana guru mengajak siswa belajar di luar kelas untuk melihat peristiwa langsung di lapangan dengan tujuan untuk mengakrabkan siswa dengan lingkungannya. Outdoor study dilakukan dengan memanfaatkan lingkungan sekolah sebagai sumber belajar. Peran guru di sini adalah sebagai motivator, artinya guru sebagai pemandu agar siswa belajar aktif, kreatif dan akrab dengan lingkungan (Husamah, 2012, hal. 23).

Manfaat dari outdoor study antara lain, (1) pikiran lebih jernih, (2) pembelajaran akan terasa menyenangkan, (3) pembelajaran lebih variatif, (4) belajar lebih rekreatif, (5) belajar lebih rill, (6) anak lebih mengenal pada dunia nyata dan luas, (7) tertanam image bahwa dunia sebagai kelas, (8) wahana belajar akan lebih luas dan (9) kerja otak lebih rileks (Husamah, 2013, hal. 25).

Tahap pelaksanaan outdoor study pada mata pelajaran geografi di mulai dari beberapa tahapan, yaitu: 1) tahap persiapan, 2) tahap pelaksanaannya mulai dari manajemen waktu yang dilakukan oleh guru dan 3) tahap evaluasi yang mulai dari pelaksanaan diskusi mengenai segala hasil pembelajaran (Hayani \& Santoso, 2015, hal. 29-31).

Pembelajaran di dalam kelas guru menggunakan berbagai strategi yang aktif dan kontekstual, melibatkan pembelajaran bersama atau pembelajaran kooperatif 
(cooperative learning) yang mengakomodasi perbedaan gender, kemampuan, sikap, dan gaya belajar masing-masing pembelajar, guna memaksimalkan kemampuan pembelajar untuk memahami dan dapat menggunakan informasi baru yang diajarkan. Pembelajaran kreatif merupakan proses pembelajaran yang mengharuskan guru dapat memotivasi dan memunculkan kreativitas peserta didik selama pembelajaran berlangsung, membuat sesuatu, menciptakan sesuatu, mengubah, mengkreasikan sesuatu, sebagai penunjang tumbuhnya kreativitas di kelas. Pembelajaran sebaiknya diformulasi untuk dapat membuat peserta didik menjadi kreatif (Saefuddin, 2014, hal. 33).

Lingkungan berdasarkan UU No. 32 Tahun 2009 tentang Pengelolaan dan Perlindungan Lingkungan Hidup adalah kesatuan ruang dengan semua benda, daya, keadaan, dan makhluk hidup termasuk di dalamnya manusia dan perilakunya, yang mempengaruhi kelangsungan perikehidupan dan kesejahteraan manusi serta makhluk hidup lainnya (Zulkifli, 2014, hal. 11).

Lingkungan berbeda-beda menurut disiplin ilmu yang dipunyai. Ahli cuaca dan iklim lingkungan berarti atmosfer, sedangkan ahli teknologi lingkungan, maka lingkungan berarti atmosfer dengan ruangannya. Ahli ekologi berpendapat bahwa lingkungan sama artinya dengan habitat hewan dan tumbuhan (Mukono, 2011, hal. 8).

Peduli lingkungan adalah tendensi mental seseorang dalam bentuk tingkah laku ke arah positif terhadap kondisi lingkungan. Dengan demikian, penilaian terhadap sikap peduli lingkungan seseorang dapat dilakukan dengan melihat respons yang teramati ketika seseorang menghadapi kondisi suatu lingkungan (Suciati, Yanti \& Listiani, 2015, hal. 252).

Kepedulian lingkungan terdiri atas 3 macam aspek yaitu (1) aspek kognitif berkaitan dengan pengetahuan seseorang terhadap lingkungan yang merupakan representasi tentang apa yang diketahui, dipahami dan dipercayai oleh individu. (2) Aspek afektif yaitu perasaan atau emosi seseorang terhadap lingkungan secara positif atau negatif (tidak memihak). (3) Aspek konatif yaitu kecenderungan berperilaku seseorang terhadap lingkungan sebagai obyek sikap yang dihadapi dalam bentuk perilaku yang dapat diamati secara langsung (Suciati, Yanti \& Listiani, 2015, hal. 252).

Lokus kontrol adalah konsep yang menjelaskan apakah seseorang merasa bahwa pengendalian hidup mereka berada dalam genggaman tangan mereka sendiri (internal locus of control) ataukah berada pada genggaman tangan orang atau hal lainnya (external locus of control). Lokus kontrol berdasarkan pada pendekatan Rotter, dapat dibagi menjadi dua yaitu internal dan eksternal. Seseorang dengan locus of control internal tinggi percaya bahwa hasil dari peristiwa-peristiwa terutama dipengaruhi oleh perilaku dan tindakannya sendiri. Sebaliknya seseorang dengan locus of 
control eksternal tinggi percaya bahwa nasib atau peruntungan yang menentukan peristiwaperistiwa dalam hidup mereka, termasuk kesuksesan ataupun kegagalan (Achadiyah \& Laily, 2003, hal. 12).

Locus of control merupakan variabel utama untuk menjelaskan perilaku manusia dalam organisasi. Locus of control adalah tingkatan dimana individu berkeyakinan bahwa hasil. Suatu peristiwa dimana seseorang merasakan yang terjadi dalam kehidupan tergantung pada perilaku atau karakteristik pribadi (Respati, 2011, hal. 128).

Seseorang yang bertipe kepribadian ekstrovert lebih suka pergaulan, tidak kaku dan canggung, senang dalam kegiatan sosial. Seseorang biasa tampil hangat dan membawa suasana mencair dalam diskusi dan pertemuan-pertemuan. Banyak orang menyatakan bahwa orang tersebut pandai bergaul dan menyenangkan. Sedangkan seseorang dengan kepribadian introvert pada umumnya pendiam, kurang hangat kepada orang lain, tidak suka bicara, mudah tersinggung, kurang percaya diri, kurang bergaul dan lebih pemalu (Surya \& Hariwijaya, 2012, ha;. 6). Dimensi dasar kepribadian mencakup apakah orang cenderung menjadi tidak bergaul, diam dan pasif (introvert) atau mudah bergaul, santai dan aktif (ekstrovert) (Pervin, Cervone, \& Jhon, 2012, hal. 244).

\section{METODE}

Penelitian ini merupakan penelitian kuantitatif dengan pendekatan eksperimen semu (quasi experiment). Dalam penelitian ini, tidak semua variabel dapat dikontrol mengingat hasil belajar geografi siswa dipengaruhi oleh banyak faktor penelitian. Penelitian ini bertujuan untuk mengetahui keefektifan model pembelajaran dan mencari interaksi antara variabel bebas (X) dan terikat (Y).

Penetapan jenis penelitian ini karena, pada akhirnya hasil penelitian ini akan menegaskan bagaimana kedudukan hubungan kasual antar variabel-variabel yang diteliti. Tujuannya terletak pada penemuan faktafakta akibat dari, perbedaan pengaruh pemberian perilaku pembelajaran yang berbeda yaitu pembelajaran outdoor study dan indoor study terhadap hasil belajar Geografi berdasarkan locus of control (kepribadian) yang dimiliki oleh siswa, baik golongan kepribadian introvert maupun extrovert. Penelitian quasi eksperimen ini menggunakan factorial design. Untuk mengidentifikasi perbedaan pengaruh antara variabel yang perlu digunakan desain factorial 2x4

Penelitian ini dilaksanakan Kota Palembang. Penelitian dilakukan di bulan April 2016 s.d mei 2016, T.A 2015/2016 semester genap. Pemilihan lokasi penelitian karena kedua sekolah menggunakan kurikulum KTSP. Teknik pengumpulan data digunakan dengan cara: (1) Tes berupa pertanyaan-pertanyaan dalam bentuk pilihan ganda dengan empat pilihan jawaban pada mata pelajaran geografi kelas XI IPS SMAN 12 dan SMAN 20 Kota Palembang dengan 
standar kompetensi (SK) 3.2 Menganalisis Pemanfaatan dan Pelestarian Lingkungan Hidup sebanyak 30 soal. (2) Non-tes berupa angket kepedulian siswa sebanyak 28 butir pernyataan dan angket locus of control sebanyak 24 butir pernyataan.

\section{HASIL DAN PEMBAHASAN}

Efektifitas metode dapat diketahui dengan adanya perbedaan yang nyata hasil belajar dan kepedulian lingkungan pada siswa metode indoor study dan outdoor study. Ada perbedaan yang nyata jika nilai signifikansi di bawah 0,05 dan nilai F hitung diatas $\mathrm{F}$ tabel. Berikut ini adalah hasil perhitungan dengan anova.

Perbedaan Hasil Belajar Geografi Pada Aspek Kognitif antara Metode Outdoor

\section{Study dan Indoor Study}

Pada hasil belajar, diperoleh hasil perhitungan menunjukkan nilai $F$ hitung metode pembelajaran terhadap hasil belajar yaitu 12,825 dan signifikansi 0,001 (nilai F hitung dibawah Ftabel dan signifikansi dibawah 0,05) sehingga dapat diambil kesimpulan terdapat perbedaan yang nyata hasil belajar pada siswa yang menggunakan metode indoor study dan metode outdoor study. Nilai rata-rata hasil belajar siswa dengan metode indoor study yaitu 50,07 dan dengan metode outdoor study yaitu 63,24 sehingga hasil belajar siswa dengan metode outdoor study lebih baik dari pada metode indoor study. Dapat diartikan bahwa metode outdoor study efektif dalam meningkatkan hasil belajar kognitif siswa.
Outdoor study merupakan metode pembelajaran yang melibatkan secara maksimal sebuah kemampuan siswa untuk mengetahui dan menyelidiki secara sistematis, kritis dan logis sehingga mereka dapat merumuskan sendiri penemuannya di lapangan dengan rasa percaya diri. Metode pembelajaran ini berpusat pada peserta didik dimana kelompok-kelompok peserta didik ke dalam suatu permasalahan atau dari sebuah peristiwa tersebut maka metode outdoor study merupakan proses pembelajaran yang menciptakan peserta didik yang subjektif, dimana guru bertindak sebagai fasilitator pengalaman belajar serta menciptakan dan mengukur kondisi yang dapat memberikan rangsangan kepada peserta didik untuk mengajukan berbagai pertanyaan tentang topik yang sedang di bahas.

\section{Perbedaan Sikap Peduli Lingkungan}

\section{Antara Metode Outdoor Study dan Indoor}

\section{Study}

Pada sikap peduli lingkungan, diperoleh hasil perhitungan menunjukkan nilai $\mathrm{F}$ hitung metode pembelajaran terhadap sikap peduli lingkungan yaitu 7,197 dan signifikansi 0,000 (nilai $F$ hitung dibawah $F$ tabel dan signifikansi dibawah 0,05) sehingga dapat diambil kesimpulan terdapat perbedaan yang nyata sikap peduli lingkungan pada siswa yang menggunakan metode indoor study dan metode outdoor study. Nilai rata-rata sikap peduli lingkungan siswa dengan metode indoor study yaitu 89,63 dan dengan metode outdoor study yaitu 96,31 sehingga sikap 
peduli lingkungan siswa dengan metode outdoor study lebih baik dari pada metode indoor study. Dapat diartikan bahwa metode outdoor study efektif dalam meningkatkan sikap peduli lingkungan siswa.

Kepedulian terhadap lingkungan diungkapkan dalam bentuk ungkapan verbal dan perilaku (tindakan nyata). Perilaku peduli lingkungan merupakan bagian tindakan yang dihasilkan dari pemahaman mengenai lingkungan. Pemahaman tersebut akan tertanam dalam diri masyarakat yang berupa perilaku positif tentang lingkungan hidup. Dari sikap inilah yang dipraktikkan melalui suatu perilaku/tindakan yang peduli lingkungan dengan melakukan pelestarian. Perilaku peduli terhadap lingkungan dapat tercermin dalam membuang sampah pada tempatnya, tidak mencemari lingkungan dan sebagainya. Pemahaman seseorang mengenai suatu objek akan menentukan perilakunya. Hal ini sejalan dengan teori lapangan Field Theory yang dikemukakan oleh Kurt Lewin dalam teorinya ia mengemukakan bahwa organisme dalam bertingkat laku bersifat aktif dan disertai pemahaman atau situasi yang dihadapi.

Perbedaan Hasil Belajar Geografi pada Aspek Kognitif Antara Outdoor Study dan Indoor Study pada Siswa dengan Locus of Control Ekstrovert

Pada hasil belajar, diperoleh hasil perhitungan menunjukkan nilai $\mathrm{F}$ hitung yaitu 114,782 dan signifikansi 0,000 (nilai F hitung dibawah $\mathrm{F}$ tabel dan signifikansi dibawah
0,05) sehingga dapat diambil kesimpulan terdapat perbedaan yang nyata hasil belajar pada siswa ekstrovert yang menggunakan metode indoor study dan metode outdoor study. Nilai rata-rata hasil belajar siswa ekstrovert dengan metode indoor study yaitu 42,20 dan dengan metode outdoor study yaitu 72,42, sehingga hasil belajar siswa ekstrovert dengan metode outdoor study lebih baik dari pada metode indoor study. Dapat diartikan bahwa metode outdoor study efektif dalam meningkatkan hasil belajar siswa dengan locus of control ekstrovert.

Metode pembelajaran outdoor study merupakan metode dengan pembelajaran dengan langsung berinteraksi dengan objek pembelajaran. Metode pembelajaran ini dinilai tepat digunakan untuk siswa yang memiliki locus of control ekstrovert. Hal ini dikarenakan siswa ekstrovert memiliki kecenderungan aktif, mudah menerima sesuatu hal baru, dan lebih terbuka. Hal ini memberikan kemudahan bagi siswa ekstrovert untuk menerima pelajaran dengan metode outdoor study. Metode ini dapat memberikan pembelajaran yang menyenangkan bagi siswa ekstrovert. Pada siswa introvert, metode pembelajaran ini akan sulit diterima oleh siswa. Hal ini dikarenakan siswa introvert memiliki kecenderungan untuk belajar dalam tempat yang kondusif dan tenang, sehingga metode outdoor study kurang tepat jika diterapkan pada siswa dengan locus of control introvert. Siswa yang memiliki locus of control ekstrovert lebih suka dengan guru 
yang memberikan pelajaran dengan pembelajaran bersifat kelompok, adan ya kerja sama dan aspek sosial di dalam maupun di luar kelas dan suasana terbuka sehingga mengundang untuk berdiskusi.

Perbedaan Sikap Peduli Lingkungan Antara Metode Outdoor Study dan Indoor Study pada Siswa dengan Locus of Control

\section{Ekstrovert}

Metode pembelajaran efektif terhadap peningkatan sikap peduli lingkungan, terbukti. Hal ini dibuktikan dengan hasil perhitungan menunjukkan nilai $\mathrm{F}$ hitung yaitu 32,442 dan signifikansi 0,000 (nilai F hitung dibawah Ftabel dan signifikansi dibawah $0,05)$ sehingga dapat diambil kesimpulan terdapat perbedaan yang nyata sikap peduli lingkungan pada siswa ekstrovert yang menggunakan metode indoor study dan metode outdoor study. Nilai rata-rata sikap peduli lingkungan siswa ekstrovert dengan metode indoor study yaitu 87,75 dan dengan metode outdoor study yaitu 102,25, sehingga sikap peduli lingkungan siswa ekstrovert dengan metode outdoor study lebih baik dari pada metode indoor study. Dapat diartikan bahwa metode outdoor study efektif dalam meningkatkan sikap peduli lingkungan siswa dengan locus of control ekstrovert.

Seseorang yang locus of control ekstrovert lebih suka pergaulan, tidak kaku dan canggung, senang dalam kegiatan sosial. Seseorang biasa tampil hangat dan membawa suasana mencair dalam diskusi dan pertemuan-pertemuan. Banyak orang menyatakan bahwa orang tersebut pandai bergaul dan menyenangkan. Sedangkan seseorang dengan locus of control introvert pada umumnya pendiam, kurang hangat kepada orang lain, tidak suka bicara, mudah tersinggung, kurang percaya diri, kurang bergaul dan lebih pemalu (Surya \& Hariwijaya, 2012, hal. 6). Hal inilah yang menyebabkan pada siswa ekstrovert dengan metode pembelajaran outdoor study lebih baik jika dibandingkan siswa introvert.

\section{Perbedaan Hasil Belajar Geografi Pada} Aspek Kognitif Antara Metode Outdoor Study dan Indoor Study pada Siswa dengan Locus of Control Introvert

Metode mempengaruhi hasil belajar siswa yang memiliki locus of control introvert. Hal ini dibuktikan dengan nilai $\mathrm{F}$ hitung yaitu 6,870 dan signifikansi 0,015 sehingga dapat diambil kesimpulan terdapat perbedaan yang nyata hasil belajar pada siswa introvert yang menggunakan metode indoor study dan metode outdoor study. Nilai ratarata hasil belajar siswa introvert dengan metode indoor study yaitu 56,36 dan dengan metode outdoor study yaitu 44,90, sehingga hasil belajar kognitif siswa introvert dengan metode indoor study lebih baik dari pada metode outdoor studyl. Dapat diartikan bahwa metode indoor study efektif dalam meningkatkan hasil belajar kognitif siswa dengan locus of control introvert.

Hasil belajar adalah suatu hasil yang diperoleh peserta didik setelah melalui aktivitas belajar yang berupa pengetahuan 
disertai dengan perubahan peningkatan dalam diri peserta didik yang dinyatakan dalam skor yang di peroleh dengan cara evaluasi atau hasil tes. Penggunaan metode pembelajaran yang tepat dapat memaksimalkan fungsi dan tujuan dari metode pembelajaran tersebut. Siswa yang memiliki locus of control introvert memiliki kecenderungan memiliki watak yang tenang, suka menyendiri, pendiam lebih baik jika diberikan metode pembelajaran indoor study. Sebaliknya, siswa yang memiliki locus of control ekstrovert akan merasa bahwa belajar dalam ruangan akan membatasi cara berpikir siswa sehingga siswa dengan locus of control ini akan sulit menerima pelajaran dengan metode indoor study.

Siswa yang memiliki locus of control introvert cenderung lebih suka dengan guru yang memberikan pembelajaran hanya dengan metode yang bersifat penugasan, siswa kurang bisa bekerja sama, kurang menghargai orang lain dan cenderung tidak peduli dengan orang lain biasanya pasif lebih cenderung senang mendengarkan pelajaran yang disampaikan oleh guru di dalam kelas.

\section{Perbedaan Sikap Peduli Lingkungan}

Antara Metode Outdoor Study dan Indoor Study pada Siswa dengan Locus of Control

\section{Introvert}

Pada sikap peduli lingkungan, diperoleh hasil perhitungan menunjukkan nilai $\mathrm{F}$ hitung yaitu 5,205 dan signifikansi 0,031 sehingga dapat diambil kesimpulan terdapat perbedaan yang nyata sikap peduli lingkungan pada siswa introvert yang menggunakan metode indoor study dan metode outdoor study. Nilai rata-rata sikap peduli lingkungan siswa introvert dengan metode indoor study yaitu 91,13 dan dengan metode outdoor studyl yaitu 84,42, sehingga sikap peduli lingkungan siswa introvert dengan metode indoor study lebih baik dari pada metode outdoor study.

Metode indoor study efektif dalam meningkatkan sikap peduli lingkungan siswa dengan locus of control introvert. Seseorang dengan locus of control introvert pada umumnya pendiam, kurang hangat kepada orang lain, tidak suka bicara, mudah tersinggung, kurang percaya diri, kurang bergaul dan lebih pemalu (Surya \& Hariwijaya, 2012, hal. 6). Siswa yang memiliki locus of control ini akan sulit untuk berinteraksi dengan lingkungannya.

Pemberian metode pembelajaran indoor study dinilai lebih efektif jika diterapkan pada siswa introvert. Hal ini dikarenakan tipe siswa introvert lebih menyukai metode pembelajaran yang tidak mengharuskan siswa berinteraksi dengan lainnya. Sistem belajar mengajar dibawah dikelas mendukung siswa introvert untuk lebih mudah menerima materi pelajaran.

\section{Interaksi Antara Metode Pembelajaran} dan Locus of Control Terhadap Hasil

\section{Belajar Kognitif Geografi}

Pengaruh variabel metode pembelajaran dan locus of control terhadap hasil belajar kognitif siswa dapat diketahui pada hasil interaksi. Nilai uji F interaksi pada hasil 
belajar yaitu 69,659 (F hitung diatas Ftabel) dan nilai signifikansi yaitu 0,000 (signifikansi dibawah 0,05). Dapat diartikan terdapat interaksi antara metode pembelajaran dan locus of control terhadap hasil belajar kognitif siswa.

Pada hasil interaksi menunjukkan bagaimana hasil belajar kognitif pada siswa dengan metode pembelajaran tertentu dan jenis locus of control tertentu. Nilai rata-rata hasil belajar kognitif menunjukkan bahwa siswa dengan locus of control introvert lebih tepat mendapatkan metode pembelajaran indoor study dengan nilai rata-rata yaitu 56,36 sedangkan siswa introvert dengan metode outdoor study yaitu 44,90. Hasil belajar kognitif siswa dengan locus of control ekstrovert lebih baik mendapatkan metode pembelajaran outdoor study dengan rata-rata 72,42 sedangkan siswa ekstrovert dengan metode indoor study dengan rata-rata 42,20. Secara keseluruhan, siswa dengan locus of control ekstrovert dan mendapatkan metode pembelajaran outdoor study memiliki nilai hasil belajar kognitif yang lebih tinggi dari yang lainnya.

Adanya interaksi metode pembelajaran dan locus of control dapat diartikan bahwa metode dan locus of control mampu mempengaruhi hasil belajar kognitif siswa dimana metode pembelajaran outdoor study tidak selamanya memberikan hasil belajar kognitif yang tinggi pada siswa, namun hal ini juga melihat bagaimana locus of control tersebut. Begitu pula pada metode pembelajaran introvert tidak selamnya memberikan hasil belajar kognitif siswa yang rendah, namun tergantung pada locus of control. Oleh karena itu, pemberian metode yang tepat pada locus of control siswa akan memberikan hasil belajar kognitif yang maksimal pada siswa.

\section{Interaksi Antara Metode Pembelajaran} dan Locus of Control Terhadap Sikap

\section{Peduli Lingkungan}

Pengaruh variabel metode pembelajaran dan locus of control terhadap sikap peduli lingkungan dapat diketahui pada hasil interaksi. Nilai uji F interaksi pada sikap peduli lingkungan yaitu 30,111 dan nilai signifikansi yaitu 0,000. Dapat diartikan terdapat interaksi antara metode pembelajaran dan locus of control terhadap sikap peduli lingkungan siswa.

Pada siswa dengan locus of control introvert dan mendapat metode pembelajaran indoor study memiliki rata-rata sikap peduli lingkungan lebih tinggi dari pada siswa kepribadian ekstrovert dengan metode indoor study. Hal ini menunjukkan bahwa untuk meningkatkan sikap peduli lingkungan siswa introvert lebih tepat diberikan metode indoor study. Pada siswa dengan locus of control ekstrovert dengan metode pembelajaran outdoor study menunjukkan rata-rata sikap peduli lingkungan yang lebih tinggi dari siswa dengan locus of control introvert dengan metode outdoor study. Adanya interaksi metode pembelajaran dan locus of control dapat diartikan bahwa metode pembelajaran 
dan locus of control mampu mempengaruhi sikap peduli lingkungan siswa. Pemberian metode pembelajaran yang tepat pada locus of control akan memberikan sikap peduli lingkungan yang maksimal pada siswa.

\section{SIMPULAN}

Terdapat perbedaan hasil belajar geografi pada aspek kognitif antara metode outdoor study dan indoor study, terdapat perbedaan sikap peduli lingkungan antara metode outdoor study dan indoor study, terdapat perbedaan hasil belajar geografi pada aspek kognitif antara metode outdoor study dan indoor study pada siswa dengan locus of control ekstrovert, terdapat perbedaan sikap peduli lingkungan antara outdoor study dan indoor study pada siswa dengan locus of control ekstrovert, Terdapat perbedaan hasil belajar geografi pada aspek kognitif antara outdoor study dan indoor study pada siswa dengan locus of control introvert, terdapat perbedaan sikap peduli lingkungan antara outdoor study dan indoor study pada siswa dengan locus of control introvert, terdapat terdapat interaksi antara metode pembelajaran dan locus of control terhadap hasil belajar kognitif sehingga outdoor study lebih efektif untuk peserta didik bertipe ekstrovert dan outdoor study tidak efektif untuk peserta didik bertipe introvert, terdapat interaksi antara metode pembelajaran dan locus of control terhadap sikap peduli lingkungan sehingga outdoor study lebih efektif untuk peserta didik bertipe ekstrovert dan outdoor study tidak efektif untuk peserta didik bertipe introvert.

\section{DAFTAR PUSTAKA}

Achadiyah \& Laily. (2013). Pengaruh locus of control terhadap hasil belajar mahasiswa akuntansi. Jurnal Pendidikan Akuntansi Indonesia. 11-18, Vol. XI, No. 2.

Arifin. (2011). Konsep dan model pengembangan kurikulum. Bandung: PT. Remaja Rosdakarya.

Assa. (2015). Strategy of learning. Yogyakarta: Araska.

Danarti. (2014). Perbedaan hasil belajar IPS model project-based learning berbasis outdoor study dengan konvensional siswa SMP. Jurnal Pendidikan Humaniora. Vol. 2 No. 2, Hal 102-111 ISSN: 23388110.

Fatemi, \& Hoseiniyan. (2016). Study of locus of control in female and male msc students. The International Journal of Indian Psychology ISSN 2348-5396 (e) | ISSN: 2349-3429 (p) Volume 3, Issue 3, No. 9, DIP: 18.01.154/20160303 ISBN: 978-1-365-13820-1.

Ghosh,. Mar (2014). Environmental Awareness Among Secondary School Students of Golaghat District in the State of Assam and Their Attitude Towards Environmental Education. IOSR Journalo of Humanities and Social Science (IOSR-JHSS)Volume 19, Issue 3, PP 30-34e-ISSN: 2279-0837, p-ISSN: 2279-0845.

Husamah. (2013). Pembelajaran luar kelas outdoor learning. Jakarta: Prestasi Pustaka Jakarta.

Mukono. (2011). Prinsip dasar kesehatan lingkungan. Surabaya: Unair (AUP).

Nasution. (2006). Pengembangan dan Implementasi Kurikulum 2013. Jakarta: Bumi Aksara.

Respati. (2011). Pengaruh locus of control terhadap hubungan sikap manajer, norma-norma subyektif, kendali perilaku persepsian, dan intensi manajer dalam melakukan kecurangan penyajian laporan keuangan. Jurnal Akuntansi dan Keuangan Indonesia Volume 8 - No. 2. 
Rinn, Boazman, Jackson \& Barrio Oktober (2014). Locus of control, academic selfconcept, and academic dishonesty among high ability college students, pp. 88 114.

Saefuddin. (2014). Pembelajaran efektif. Jakarta: Remaja Rosda Karya.

Suciati, Yanti \& Listiani. (2015). Perbedaan penerapan pembelajaran biologi model sts terhadap peningkatan sikap peduli lingkungan siswa ditinjau dari jenjang pendidikan. SP 006-041.

Suprijono. (2011). Cooperative learning. Yogyakarta: Pustaka Pelajar.

Surya \& Hariwijaya. (2012). Tes bakat dan kepribadian. Yogyakarta: PT. Citra Aji Parama.

Zaidi \& Mohsin. (2013). Locus of control in graduation students, PP 15-20, ISSN printed 2011-2084.

Zulkifli. (2014). Dasar-dasar ilmu kelingkungan. Jakarta: Salemba Teknika 